\title{
Simpanan Karbon Pada Padang Lamun di Kawasan Pantai Mengiat, Nusa Dua Bali
}

\author{
I Kadek Vidyananda S Rahadiarta ${ }^{* *}$, I Dewa Nyoman Nurweda Putra a, Yulianto Suteja ${ }^{a}$ \\ a Program Studi Ilmu Kelautan, Fakultas Kelautan dan Perikanan, Universitas Udayana, Kampus UNUD Bukit Jimbaran, Bali 80361, Indonesia \\ * Penulis koresponden. Tel.: +62-812-3851-9928 \\ Alamat e-mail: vidyanandasr@gmail.com
}

Diterima (received) 3 Oktober 2017; disetujui (accepted) 1 Februari 2018; tersedia secara online (available online) 5 Februari 2018

\begin{abstract}
Human activity is the most contributor of carbon dioxide gas $\left(\mathrm{CO}_{2}\right)$ to the air. The oceans have an important role in the carbon cycle, about $93 \%$ of the Earth's $\mathrm{CO}_{2}$ is stored in the oceans. Seagrass is one of sea plants that has a role as carbon sinks in ocean. Seagrass beds are able to absorb carbon by an average 0.21 tons/ha and the important species are Enhalus acoroide. The aim of this study is determine the carbon storage in seagrass at aboveground (leaf), belowground (roots and rhizomes) and carbon storage on each species of seagrass obtained at Mengiat coastal area. Determination of sampling point refer to seagrass density that used by purposive sampling. This method was assumed to represent or describe the condition of this area. This research used dry dyeing method which components sample was destruction with $500^{\circ} \mathrm{C}$ inside the furnace. The results showed that carbon storage of seagrass at belowground (root and rhizoma) is $25.70 \mathrm{gC} / \mathrm{m}^{2}$, and aboveground (leaf) is $17.18 \mathrm{gC} / \mathrm{m}^{2}$. Carbon storage at belowground is higher than aboveground because carbon will accumulate in the sediment. The type of seagrass that is obtained at Mengiat coastal area is Thalassodendron ciliatum. Thalassia hemprichii, Cymodocea serrulata, Halodule uninervis, Cymodocea rotundata, and Syringodium isoetifolium, the highest carbon storage are $62.46 \mathrm{gC} / \mathrm{m}^{2}$ is owned by Thalassodendron ciliatum, and the lowest carbon storages are $17.25 \mathrm{gC} / \mathrm{m}^{2}$ is owned by Syringodium isoetifolium.
\end{abstract}

Keywords: seagrass; carbon storage; Mengiat coastal area

\begin{abstract}
Abstrak
Aktivitas manusia adalah penyumbang gas karbon dioksida $\left(\mathrm{CO}_{2}\right)$ terbanyak ke udara. Lautan memiliki peranan yang penting dalam siklus karbon, sekitar $93 \% \mathrm{CO}_{2}$ di bumi disimpan dalam lautan. Lamun merupakan salah satu tumbuhan laut yang berperan sebagai penyerap karbon di lautan. Padang lamun mampu menyerap karbon dengan rata-rata 0,21 ton/ha dan jenis yang berperan penting yakni Enhalus acoroides. Tujuan penelitian ini untuk mengetahui simpanan karbon pada lamun di bagian atas substrat (daun), bagian bawah substrat (akar dan rhizoma) dan pada setiap jenis lamun yang didapat di Pantai Mengiat. Penentuan titik pengambilan sampel mengacu pada kerapatan lamun yang dilakukan dengan metode purposive sampling. Metode ini diasumsikan bisa mewakili atau menggambarkan keadaan perairan tersebut. Penelitian ini menggunakan metode pengabuan kering yang dilakukan dengan penghancuran komponen sampel pada suhu $500^{\circ} \mathrm{C}$ di dalam tanur listrik. Hasil penelitian menunjukkan kandungan karbon lamun pada bagian bawah substrat (akar dan rhizoma) sebesar $25.70 \mathrm{gC} / \mathrm{m}^{2}$, sedangkan bagian atas substrat (daun) sebesar $17.18 \mathrm{gC} / \mathrm{m}^{2}$. Kandungan karbon pada bagian bawah substrat lebih tinggi daripada bagian atas substrat karena karbon akan terakumulasi di sedimen. Jenis lamun yang didapat di Pantai Mengiat yaitu Thalassodendron ciliatum, Thalassia hemprichii, Cymodocea serrulata, Halodule uninervis, Cymodocea rotundata, dan Syringodium isoetifolium, dimana kandungan karbon tertinggi yaitu $62.46 \mathrm{gC} / \mathrm{m}^{2}$ dimiliki jenis Thalassodendron ciliatum, sedangkan kandungan karbon terendah yaitu $17.25 \mathrm{gC} / \mathrm{m}^{2}$ dimiliki jenis Syringodium isoetifolium.
\end{abstract}

Kata Kunci: lamun; simpanan karbon; Pantai Mengiat 


\section{Pendahuluan}

Perubahan iklim global akibat jumlah Gas Rumah Kaca (GRK) yang terakumulasi di atmosfer membuat radiasi matahari terperangkap di dalam atmosfer sehingga terjadi peningkatan suhu secara global (Hilwan, 2014). Emisi gas rumah kaca yang paling besar adalah $\mathrm{CO}_{2}$ (Uthbah, 2017).

Karbon merupakan unsur yang diserap dari atmosfer dan disimpan di dalam biomassa tanaman melalui proses fotosintesis (Yuniawati, 2014). Perubahan iklim yang drastis akibat aktivitas manusia telah menyumbangkan gas karbon dioksida yang cukup banyak ke udara dan atmosfer bumi (Hartati, 2017). Sekitar 93\% $\mathrm{CO}_{2}$ di bumi disimpan dalam lautan menjadikan lautan memiliki peranan yang penting dalam siklus karbon (Rahmawati, 2011).

Berdasarkan penelitian Graha (2016), lamun merupakan salah satu sumberdaya laut yang berperan sebagai penyerap gas $\mathrm{CO}_{2}$. Lamun melakukan proses fotosintesis menghasilkan bahan organik dari bahan anorganik dengan bantuan sinar matahari (Supriadi, 2012). Hasil penyerapan karbon oleh lamun pada proses fotosintesis disimpan dalam bentuk biomassa, baik di atas maupun di bawah substrat (Supriadi, 2014).

Lamun (seagrass) adalah tumbuhan berbunga yang sudah menyesuaikan hidupnya terbenam di dalam laut (Rahman, 2016). Padang lamun mampu menyerap karbon dengan rata-rata 0,21 ton/ha dan jenis yang berperan penting yakni Enhalus acoroides (Graha, 2016). Menurut penelitian Supriadi (2014), padang lamun mampu menyerap karbon sebesar 1.15 ton/ha, dengan kandungan karbon di bawah substrat sebesar 0.88 ton/ha (76.3\%), lebih tinggi dibanding karbon di atas substrat yang hanya 0.27 ton/ha $(23,7 \%)$. Potensi simpanan karbon pada lamun bagian bawah substrat berpeluang tersimpan lebih lama dan terus bertambah jika ekosistem lamun terjaga dari kerusakan, sementara bagian atas substrat lebih banyak termanfaatkan dalam rantai makanan (Rustam, 2014).

Adanya aktivitas manusia, pariwisata serta pembangunan seperti hotel dan reklamasi Pulau Serangan berdampak pada kondisi padang lamun di Bali yang mengakibatkan banyak terjadinya degradasi (Arthana, 2012). Wilayah pesisir Bali memiliki luas lamun yaitu sekitar 1.316 ha dan data kerusakan padang lamun di Bali berkisar 8 -
30,23\% (Sudiarta, 2011). Menurut Setiawan (2012) potensi penyerapan karbon akan berbanding lurus dengan luas area lamun, dimana semakin tinggi luas area lamun yang dimiliki suatu perairan potensi penyerapan karbonnya juga akan tinggi. Salah satu lokasi padang lamun di Bali yang sering dimanfaatkan oleh masyarakat sekitar adalah di daerah Selatan Bali (Faiqoh, 2017). Menurut Yusup (2010), terdapat 8 jenis lamun yang ada di perairan Bali yaitu Enhalus acoroides, Halophila decipiens, Thalassia hempricii, Cymodocea rotundata, Cymodocea serrulata, Halodule uninervis, Syringodium isoetifolium dan Thalassodedron ciliatum. Salah satu tempat tumbuhnya lamun yaitu di Pantai Mengiat, yang berlokasi di wilayah Nusa Dua.

Pantai Mengiat merupakan salah satu objek wisata di wilayah Nusa Dua yang menawarkan ketenangan. Lokasi dengan kondisi seperti ini banyak dimanfaatkan untuk kegiatan renang, wisata serta pembangunan hotel di bibir pantai. Keberadaan hotel yang terletak di bibir pantai membawa dampak buruk baik secara langsung maupun tidak langsung bagi keberlangsungan hidup padang lamun. Akibatnya lamun yang tumbuh alami tersebut semakin hari semakin tertekan yang mengarah kepada terjadinya degradasi. Dikhawatirkan terjadinya degradasi pada padang lamun ini akan terus meningkat akibat berkembangnya aktivitas manusia di daerah pesisir (Fajarwati, 2015).

Penelitian mengenai kandungan karbon bagian bawah dan atas subtrat pada lamun belum pernah dilakukan sebelumnya di Pantai Mengiat, oleh karena itu diperlukannya penelitian tentang kandungan karbon bagian atas dan bawah substrat. Tujuan dari penelitian ini untuk mengetahui simpanan karbon pada lamun bagian atas substrat (daun), bawah substrat (akar dan rhizoma) dan simpanan karbon pada setiap jenis lamun yang didapat di Pantai Mengiat. Pada penelitian ini menggunakan metode pengabuan kering.

\section{Metode Penelitian}

\subsection{Waktu dan Lokasi Penelitian}

Penelitian ini dilaksanakan selama bulan April 2017. Penelitian dilakukan di Pantai Mengiat, Nusa Dua, Kabupaten Badung, Provinsi Bali (Gambar 1). Pengolahan sampel dilakukan di Laboratorium Universitas Warmadewa. 


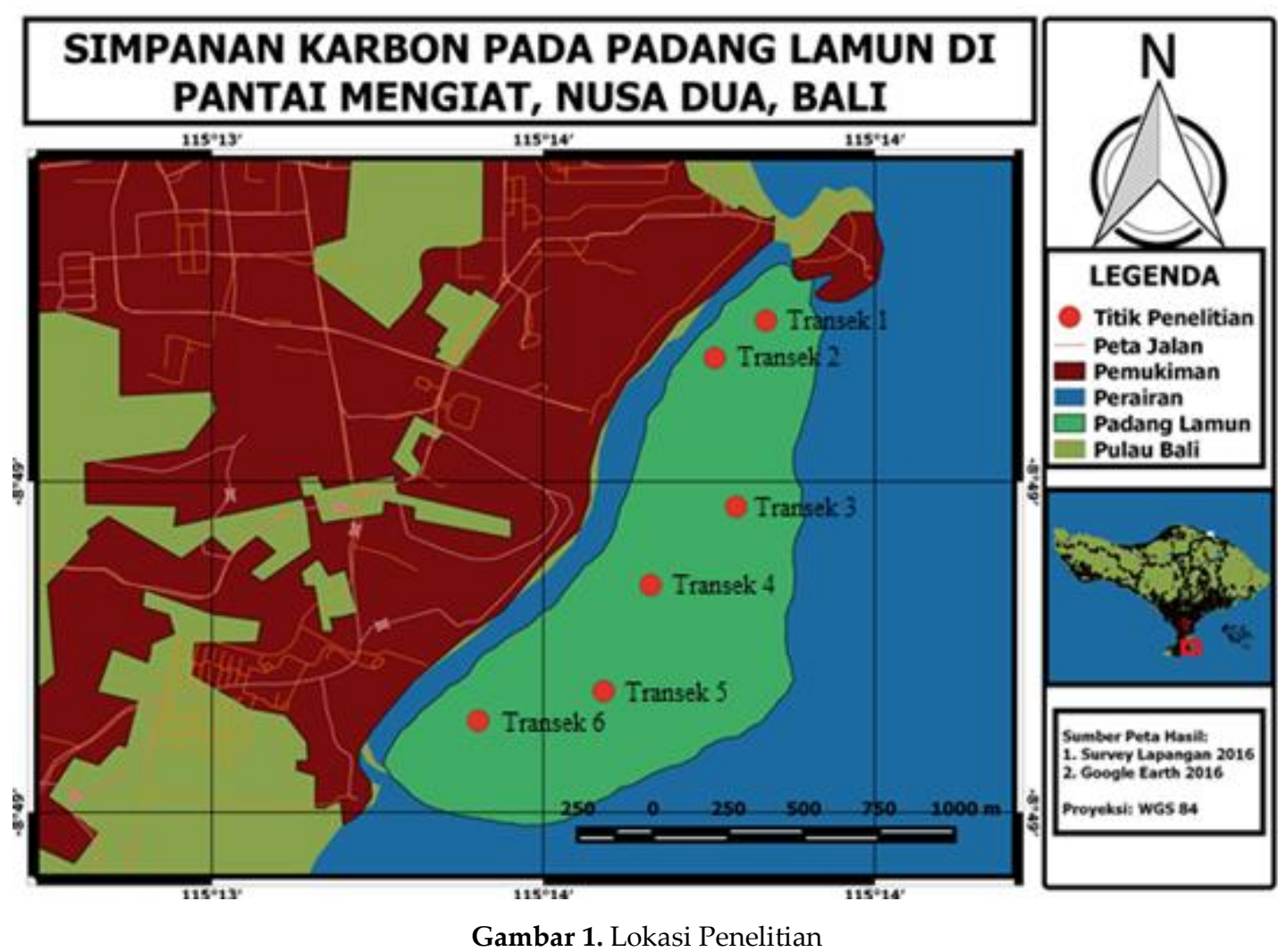

Tabel 1

Alat penelitian.

\begin{tabular}{clclc}
\hline No & Komponen yang diamati & Satuan & \multicolumn{1}{c}{ Alat } & Keterangan \\
\hline 1 & Pengamatan ekosistem & Tegakan & Alat Tulis, Transek Kuadrat, & In Situ \\
& lamun & & Kantong Sampel & In Situ \\
2 & Suhu perairan & ${ }^{\circ} \mathrm{C}$ & Thermometer & In Situ \\
3 & Salinitas & $\mathrm{Ppt}$ & Refraktometer & In Situ \\
4 & pH & - & pH Meter & In Situ \\
5 & Oksigen terlarut & Ppm & DO Meter & Laboratorium \\
6 & Analisa biomassa & & Oven & Laboratorium \\
7 & Analisa karbon & & Tanur Listrik & In Situ \\
8 & Koordinat lapangan & & GPS & In Situ \\
9 & Pengamatan lapangan & & Kamera &
\end{tabular}

\subsection{Alat dan Bahan}

Alat dan bahan penelitian merupakan segala sesuatu yang dikenai perlakuan atau yang digunakan dalam pengumpulan data. Bahan yang digunakan dalam penelitian ini adalah tumbuhan lamun sebagai objek yang diamati dan sebagai sampel jenis. Parameter lingkungan yang diteliti yaitu suhu, salinitas, $\mathrm{pH}$, dan oksigen terlarut. Diukur menggunakan thermometer, refractometer, $\mathrm{pH}$ meter, DO meter dan peralatan pendukung penelitian (Tabel 1).

\subsection{Prosedur Penelitian}

\subsubsection{Kondisi Umum Lamun}

Survei awal pengamatan kondisi umum lamun dilakukan untuk melihat distribusi lamun terkait penentuan letak transek penelitian (Graha, 2016). Pada penelitian ini penentuan titik sampling adalah sebanyak enam titik untuk pengambilan sampel lamun dilakukan secara purposive sampling mengacu pada kerapatan lamun yang diasumsikan dapat mewakili atau menggambarkan keadaan perairan tersebut. 
Bersamaan pada saat dilakukan pengamatan kondisi umum ekosistem padang lamun, dilakukan juga pengukuran parameter lingkungan yaitu berupa suhu, salinitas, $\mathrm{pH}$ dan oksigen terlarut (DO). Penelitian dilakukan dengan tahapan pengambilan sampel di lapangan, pengukuran biomassa dan pengukuran kandungan karbon di laboratorium.

\subsubsection{Kondisi Umum Lamun}

Pengambilan sampel sebagai biomassa dilakukan dengan menggunakan transek kuadrat $1 \times 1 \mathrm{~m}^{2}$ yang dibagi menjadi 25 sub petak berukuran $20 \mathrm{x}$ $20 \mathrm{~cm}$ (Gambar 2).

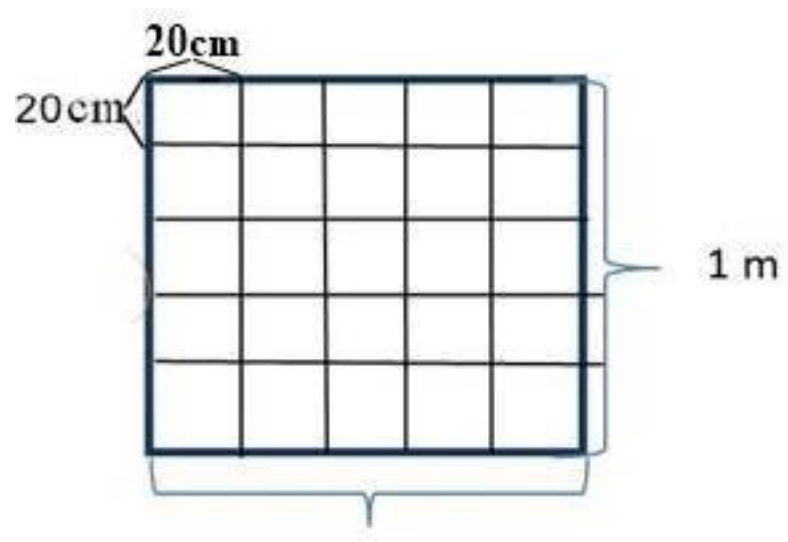

$1 \mathrm{~m}$

Gambar 2. Transek kuadrat

Pengambilan sampel lamun dilakukan dengan mencuplik menggunakan tangan sampai pada kedalaman penetrasi akar. Rhizoma yang menjalar ke luar transek dipotong untuk mempermudah pencuplikan. Sampel dimasukkan ke kantong sampel setelah dibersihkan dari substrat dan dibedakan perspesies.

\subsubsection{Pengolahan Sampel di Laboratorium}

\section{a. Biomassa Lamun}

Menghitung nilai biomassa dilakukan dengan mengambil beberapa tegakan sampel lamun dari setiap jenis yang terdapat pada transek penelitian. Lamun yang diambil diharapkan memenuhi kebutuhan sampel dalam uji laboratorium yaitu berat kering sampel antara 1 - 2 gram sesuai dengan kemampuan cawan menampung sampel. Biomassa lamun dapat dicari dengan cara lamun dikeringkan dalam oven menggunakan suhu $60^{\circ} \mathrm{C}$ selama 24 jam. Nilai biomassa lamun dibagi menjadi tiga bagian yaitu daun, rhizoma dan akar. Setelah didapatkan nilai biomassa per jaringan lamun (daun, rhizoma dan akar), dilakukan penghitungan kandungan karbon terhadap sampel biomassa.

b. Kandungan Karbon

Menghitung kandungan karbon menggunakan metode pengabuan, dilakukan dengan sampel dimasukkan ke dalam tanur listrik selama 3 - 6 jam pada suhu $500^{\circ} \mathrm{C}$ hingga menjadi abu yang ditandai oleh warna putih keabu-abuan. Metode pengabuan bertujuan mengoksidasi semua zat organik pada suhu tinggi, kemudian dilakukan penimbangan zat yang tertinggal setelah proses pembakaran (Hafiludin, 2011). Sampel yang diambil untuk dapat memenuhi kebutuhan uji laboratorium selanjutnya di konversi ke dalam satu meter persegi.

\subsection{Analisis Data}

\subsubsection{Kerapatan Lamun}

Skala kerapatan dapat di kategorikan menjadi lima sebagai acuan dalam mengambil sampel menggunakan transek kuadrat (Tabel 2):

Rumus yang digunakan untuk menghitung kerapatan lamun seperti yang ditunjukkan oleh persamaan (1) sebagai berikut (Ira, 2013):

$D i=\sum \frac{n i}{A}$

dimana $D i$ adalah kerapatan lamun jenis-i (tegakan $\left./ \mathrm{m}^{2}\right), n i$ adalah jumlah tegakan lamun jenis-i (tegakan) dan $A$ adalah jumlah luas transek dimana lamun jenis-i ditemukan $\left(\mathrm{m}^{2}\right)$

\subsubsection{Biomassa dan Kandungan Karbon Jaringan} Lamun

Biomassa lamun dapat dicari dengan menghitung berat kering dibagi luasan area menggunakan persamaan (2) (Santoso, 2018):

$B=W / A$

dimana $B$ adalah Biomassa Lamun $\left(\mathrm{gbk} / \mathrm{m}^{2}\right)$, sedangkan $W$ adalah Berat Kering Lamun (gbk) dan $A$ adalah Luasan Area $\left(\mathrm{m}^{2}\right)$.

Hasil dari perhitungan biomassa akan digunakan dalam perhitungan Kadar abu dan Kadar Bahan Organik menjadi berat sampel pada 
rumus (3). Rumus yang digunakan untuk menghitung kadar abu pada jaringan lamun dengan metode pengabuan dapat ditunjukkan oleh persamaan (3) (Huriawati, 2016):

$\operatorname{Kadar} \operatorname{Abu}(\%)=\frac{c-a}{b-a} \times 100 \%$

dimana $a$ adalah berat cawan, $b$ adalah berat cawan + berat sampel, dan $c$ adalah berat cawan + berat abu.

Tabel 2.

Skala kondisi padang lamun berdasarkan kerapatan Amran, 2009 in Nurzahraeni, 2014).

\begin{tabular}{ccc}
\hline Skala & $\begin{array}{c}\text { Kerapatan } \\
\left.\text { tegakan } / m^{2}\right)\end{array}$ & Kondisi \\
\hline 5 & $>625$ & Sangat Rapat \\
4 & $425-624$ & Rapat \\
3 & $225-424$ & Agak Rapat \\
2 & $25-224$ & Jarang \\
1 & $<25$ & Sangat Jarang \\
\hline
\end{tabular}

Untuk menghitung bahan organik dengan metode pengabuan ini dapat ditentukan dengan menghitung pengurangan berat saat pengabuan dengan persamaan (4) (Helrich, 1990):

Kadar Bahan Organik $=\frac{[(b-a)-(c-a)]}{(b-a)} \times 100 \%$

dimana $a$ adalah berat cawan, $b$ adalah berat cawan + berat sampel, dan $c$ adalah berat (cawan + $a b u)$.

Setelah mengetahui kadar bahan organik, dilakukan penghitungan kandungan karbon jaringan lamun dengan persamaan (5) (Helrich, 1990):

Kandungan Karbon $=\frac{\text { Bahan Organik }}{1,724}$

dimana 1,724 merupakan Konstanta nilai bahan organik (Graha, 2016).

\section{Hasil dan Pembahasan}

\subsection{Kondisi Umum Lamun}

\subsubsection{Kerapatan Jenis Lamun}

Berdasarkan hasil pengamatan didapatkan enam spesies lamun di wilayah Pantai Mengiat yaitu Cymodocea serrulata, Cymodocea rotundata,
Syringodium isoetifolium, Thalassia hemprichii, Thalassodendron ciliatum dan Halodule uninervis (Tabel 3). Pada transek 1 terdapat dua jenis lamun yaitu Cymodocea serrulata dan Syringodium isoetifolium. Jenis yang mendominasi pada transek 1 adalah Cymodocea serrulata memiliki nilai kerapatan 668 tegakan $/ \mathrm{m}^{2}$ dan jenis Syringodium isoetifolium yaitu 237 tegakan $/ \mathrm{m}^{2}$. Pada transek 2 terdapat dua jenis lamun yaitu Thalassia hemprichii dan Cymodocea rotundata. Jenis yang mendominasi adalah Thalassia hemprichii memiliki nilai kerapatan 530 tegakan $/ \mathrm{m}^{2}$ dan jenis Cymodocea rotundata yaitu 386 tegakan $/ \mathrm{m}^{2}$. Pada transek 3 terdapat dua jenis lamun yaitu Cymodocea serrulata dan Cymodocea rotundata. Jenis yang mendominasi adalah Cymodocea rotundata memiliki nilai kerapatan 700 tegakan $/ \mathrm{m}^{2}$ dan jenis Cymodocea serrulata yaitu 393 tegakan $/ \mathrm{m}^{2}$. Pada transek 4 terdapat satu jenis lamun yaitu Thalassodendron ciliatum dengan nilai kerapatan 629 tegakan $/ \mathrm{m}^{2}$. Pada transek 5 terdapat dua jenis lamun yaitu Cymodocea rotundata dan Halodule uninervis. Jenis yang mendominasi adalah Halodule uninervis memiliki nilai kerapatan 596 tegakan $/ \mathrm{m}^{2}$ dan jenis Cymodocea rotundata yaitu 458 tegakan $/ \mathrm{m}^{2}$. Pada transek 6 terdapat satu jenis lamun yaitu Thalassodendron ciliatum dengan nilai kerapatan 665 tegakan $/ \mathrm{m}^{2}$.

Kerapatan lamun tertinggi terdapat pada transek 3 dengan nilai 1093 tegakan $/ \mathrm{m}^{2}$ yang menunjukkan kondisi sangat rapat (Amran, 2009 in Nurzahraeni, 2014). Transek 3 terdiri dari jenis Cymodocea serrulata dan Cymodocea rotundata. Nilai kerapatan terendah terdapat pada transek 4 dengan nilai 629 tegakan $/ \mathrm{m}^{2}$, terdiri dari jenis lamun Thalassodendron ciliatum. Kerapatan setiap jenis lamun dari seluruh transek penelitian menunjukkan lamun jenis Cymodocea rotundata memiliki nilai kerapatan $386-700$ tegakan $/ \mathrm{m}^{2}$, jenis Cymodocea serrulata memiliki nilai kerapatan 393 - 668 tegakan $/ \mathrm{m}^{2}$, jenis Syringodium isoetifolium memiliki nilai kerapatan 287 tegakan $/ \mathrm{m}^{2}$, jenis Thalassia hemprichii memiliki nilai kerapatan 530 tegakan $/ \mathrm{m}^{2}$, jenis Thalassodendron ciliatum memiliki nilai kerapatan 629 - 665 tegakan/ $/ \mathrm{m}^{2}$, dan jenis Halodule uninervis memiliki nilai kerapatan sebesar 596 tegakan $/ \mathrm{m}^{2}$. Kecilnya nilai kerapatan pada transek 4 dikarenakan morfologinya dari lamun jenis Thalassodendron ciliatum lebih besar jika dibandingkan dengan lamun jenis lainnya di lokasi penilitian. Menurut Kurnia (2015), Thalassodendron ciliatum memiliki morfologi daun berbentuk seperti sabit dan ujung daun seperti 
Tabel 3

Kerapatan lamun di Pantai Mengiat.

\begin{tabular}{|c|c|c|c|c|c|c|c|}
\hline \multirow{2}{*}{$\begin{array}{l}\text { Transek Kuadrat } \\
\qquad\left(1 \times 1 \mathrm{~m}^{2}\right)\end{array}$} & \multicolumn{6}{|c|}{ Jenis Lamun (tegakan/m²) } & \multirow{2}{*}{$\begin{array}{c}\text { Total } \\
\left(\text { tegakan } / \mathrm{m}^{2}\right)\end{array}$} \\
\hline & Cs & $S i$ & $T h$ & $\mathrm{Cr}$ & Tc & $H u$ & \\
\hline Transek 1 & 668 & 287 & - & - & - & - & 955 \\
\hline Transek 2 & - & - & 530 & 386 & - & - & 916 \\
\hline Transek 3 & 393 & - & - & 700 & - & - & 1093 \\
\hline Transek 4 & - & - & - & - & 629 & - & 629 \\
\hline Transek 5 & - & - & - & 458 & - & 596 & 1054 \\
\hline Transek 6 & - & - & - & - & 665 & - & 665 \\
\hline
\end{tabular}

Keterangan: $\mathrm{Cs}=$ Cymodocea serrulata, $\mathrm{Si}=$ Syringodium isoetifolium, $\mathrm{Th}=$ Thalassia hemprichii, $\mathrm{Cr}=$ Cymodocea rotundata, $\mathrm{Tc}=$ Thalassodendron ciliatum, $\mathrm{Hu}=$ Halodule uninervis.

gigi, memiliki rhizoma yang keras seperti kayu, serta akar memanjang dan bercabang.

\subsubsection{Biomassa Lamun}

Berdasarkan perhitungan biomassa (persamaan 2), nilai biomassa lamun tertinggi pada setiap jenis lamun dimiliki jenis Thalassodendron ciliatum sebesar $340.98 \mathrm{gbk} / \mathrm{m}^{2}$, dan nilai biomassa terendah dimiliki jenis Syringodium isoetifolium sebesar 78.37 $\mathrm{gbk} / \mathrm{m}^{2}$ (Gambar 3).

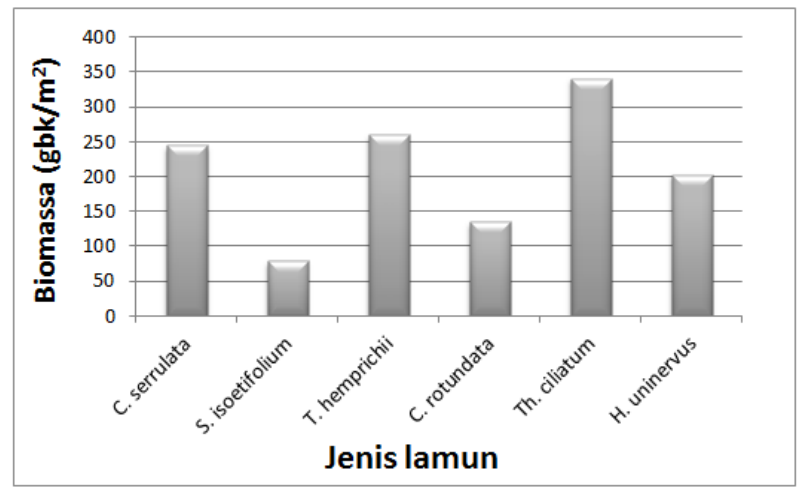

Gambar 3. Biomassa lamun per jenis.

Tingginya nilai biomassa jenis Thalassodendron ciliatum dikarenakan morfologi dari lamun tersebut lebih besar dibanding lamun jenis lainnya. Menurut Assuyuti (2016), nilai biomassa dipengaruhi oleh morfologi dari jenis lamun. Nilai biomassa terendah terdapat pada jenis Syringodium isoetifolium dikarenakan memiliki nilai kerapatan terendah. Menurut Azizah dkk. (2017), nilai biomassa dapat dipengaruhi kerapatan, dimana semakin tinggi nilai kerapatan lamun maka semakin tinggi nilai biomassa yang dihasilkan lamun tersebut.
Hasil pengukuran biomassa lamun pada bagian bagian atas substrat dan bawah substrat memiliki hasil yang berbeda (Gambar 4). Nilai total biomassa pada bagian atas subtrat dari setiap jenis lamun yang ditemukan di lokasi penelitian sebesar $76.77 \mathrm{gbk} / \mathrm{m}^{2}$. Nilai tersebut lebih rendah dibandingkan pada bagian bawah subtrat yang memiliki nilai biomassa sebesar $133.55 \mathrm{gbk} / \mathrm{m}^{2}$.

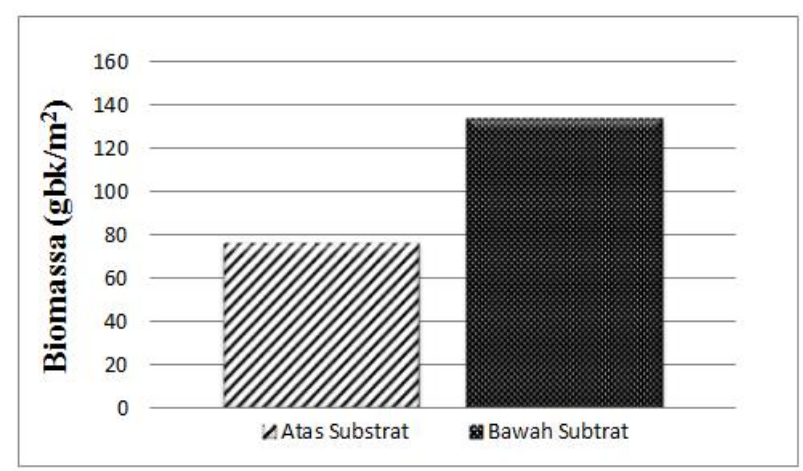

Gambar 4. Biomassa lamun atas dan bawah substrat.

Dijelaskan oleh Nasdwiana (2016), bahwa salah satu adaptasi dari tumbuhan lamun yaitu dengan mengumpulkan biomassa di bawah substrat agar dapat mencengkram substrat dengan kuat. Menurut Rahman (2016), rhizoma dan akar lamun terbenam di bawah substrat. Akar dan rhizoma di bawah substrat mampu menyerap unsur hara yang mempengaruhi biomassa lamun (Christon, et al. 2012).

\subsection{Parameter Lingkungan}

Hasil pengukuran parameter lingkungan antar setiap transek penelitian di Pantai Mengiat menunjukkan kualitas perairan untuk DO, suhu, $\mathrm{pH}$ dan salinitas cenderung sama (Tabel 4). Nilai DO di lokasi penelitian berkisar antara $7.2-7.4$ 
(mg/L) sudah masuk katagori optimum, menurut Barus (2004), nilai oksigen terlarut di perairan sebaiknya berkisar antara 6 sampai $8 \mathrm{mg} / \mathrm{l}$. Hasil pengukuran suhu dan salinitas dilapangan masing-masing memiliki nilai $28.3-28.6^{\circ} \mathrm{C}$ dan 33 - 34\%o, masuk dalam katagori optimum, dimana nilai suhu dan salinitas yang optimum bagi pertumbuhan lamun menurut KepMenLH No. 51 Th 2004 (MNLH, 2004) masing-masing memiliki nilai $28-30{ }^{\circ} \mathrm{C}$ dan $33-34 \%$. Nilai $\mathrm{pH}$ dilokasi penelitian berkisar antara $8.04-8.1$, sudah masuk dalam katagori optimum, menurut Pratiwi (2014) nilai $\mathrm{pH}$ optimum untuk pertumbuhan lamun berkisar 7,3-9,0.

Tabel 4

Parameter perairan di Pantai Mengiat

\begin{tabular}{ccccc}
\hline Transek & $\begin{array}{c}\text { DO } \\
(\mathrm{mg} / \mathrm{L})\end{array}$ & $\begin{array}{c}\text { Suhu } \\
\left({ }^{\circ} \mathrm{C}\right)\end{array}$ & $\mathrm{pH}$ & $\begin{array}{c}\text { Salinitas } \\
(\% \mathrm{o})\end{array}$ \\
\hline 1 & 7.3 & 28.5 & 8.06 & 34 \\
2 & 7.4 & 28.6 & 8.07 & 33 \\
3 & 7.2 & 28.5 & 8.1 & 34 \\
4 & 7.3 & 28.3 & 8.05 & 33 \\
5 & 7.4 & 28.3 & 8.06 & 34 \\
6 & 7.4 & 28.4 & 8.04 & 34 \\
\hline
\end{tabular}

\subsection{Karbon Lamun}

\subsubsection{Kadar Abu}

Hasil analisis dengan cara metode pengabuan menggunakan persamaan (3) dan (4) menghasilkan nilai kadar abu dan bahan organik pada bagian atas dan bawah subtrat (Gambar 5). Nilai kadar abu bagian atas substrat memiliki presentase lebih tinggi dari kandungan bahan organik yaitu $63,27 \%$ dan nilai kandungan bahan organik yaitu $36,73 \%$. Nilai kadar abu bagian bawah substrat memiliki presentase $49,40 \%$ dan kandungan bahan organik yaitu $50.60 \%$.

Nilai bahan organik bagian bawah substrat lebih tinggi dibandingkan bagian atas substrat diduga karena banyaknya sampel yang menguap selama pengabuan menandakan bahan mineral yang terkandung pada sampel lamun lebih banyak pada bagian bawah substrat. Menurut Handayani (2015) berat kering sampel yang mengalami proses penguapan selama pengovenan dapat berupa mineral organik. Kerapatan juga mempengaruhi kandungan bahan organik, menurut Riniatsih (2015), tingginya kerapatan lamun mengakibatkan banyak tumbuhan lamun mampu mengikat bahan organik di dasar perairan. Rendahnya kandungan bahan organik diatas substrat diduga akibat pengaruh fisik seperti gelombang dan paparan cahaya matahari. Menurut Supriadi (2014), rendahnya nilai bahan organik diatas subtrat berkaitan dengan posisinya yang langsung terpapar gelombang dan kekeringan akibat paparan cahaya matahari.

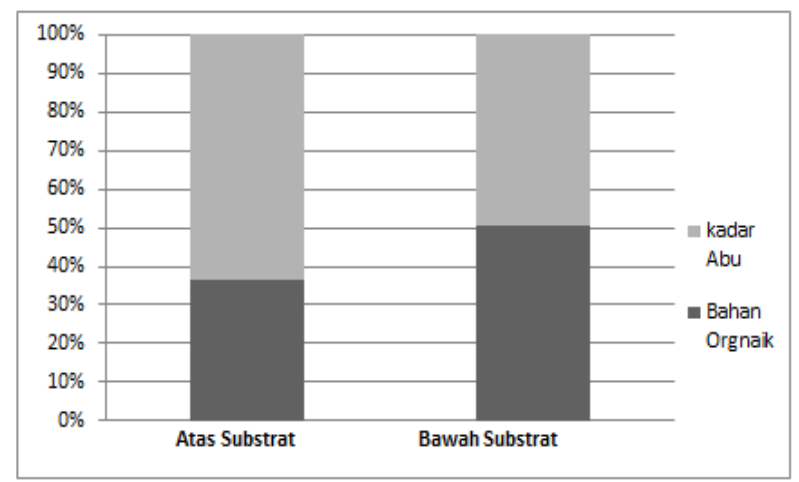

Gambar 5. Kadar abu dan bahan organik atas dan bawah substrat.

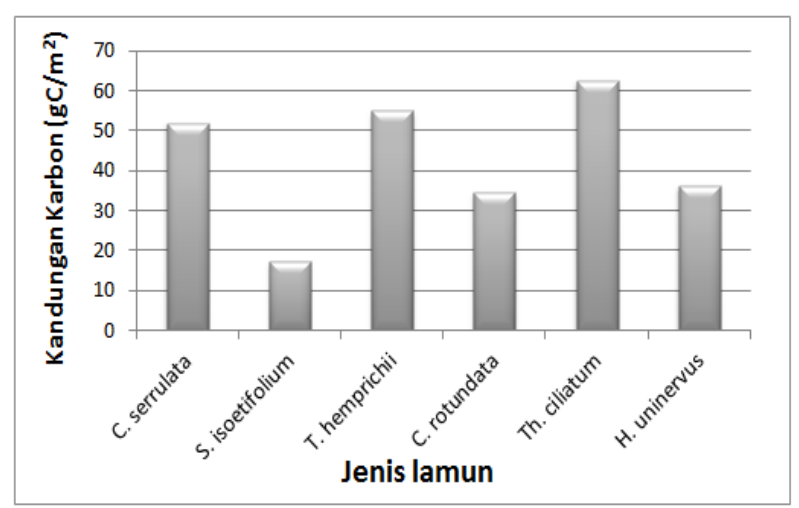

Gambar 6. Kandungan karbon lamun per jenis

\subsubsection{Kandungan Karbon}

Berdasarkan perhitungan kandungan karbon (persamaan 5), kandungan karbon lamun tertinggi terdapat pada jenis Thalassodendron ciliatum yaitu $62.46 \mathrm{gC} / \mathrm{m}^{2}$, sedangkan kandungan karbon terendah terdapat pada jenis Syringodium isoetifolium yaitu $17.25 \mathrm{gC} / \mathrm{m}^{2}$ (Gambar 6). Tingginya kandungan karbon jenis Thalassodendron ciliatum dikarenakan nilai biomassa yang lebih besar dibandingkan dengan jenis lainnya di lokasi penelitian, sedangkan rendahnya kandungan karbon dari jenis Syringodium isoetifolium dikarenakan memiliki nilai biomassa paling rendah di lokasi penelitian. Menurut Widyasari 
(2010), potensi kandungan karbon berhubungan erat dengan besarnya nilai biomassa. Hasil tersebut berbanding lurus dengan pernyataan Yuniawati, 2014 bahwa semakin besar kandungan biomassa, maka kandungan karbon juga akan semakin besar.

Hasil analisis dengan menggunakan metode pengabuan menghasilkan kandungan karbon bagian atas substrat dan bagian bawah substrat (Gambar 7). Kandungan karbon tertinggi terdapat pada bagian bawah substrat yaitu $25.70 \mathrm{gC} / \mathrm{m}^{2}$ sedangkan kandungan karbon pada bagian atas substrat sebesar $17.18 \mathrm{gC} / \mathrm{m}^{2}$. Hasil tersebut sesuai dengan penelitian Putra (2017), dimana kandungan karbon pada bagian bawah susbtrat lebih tinggi dibandingkan dengan bagian atas substrat. Menurut Supriadi (2014), tingginya nilai kandungan karbon pada bagian bawah substrat sangat penting karena karbon akan terakumulasi di sedimen.

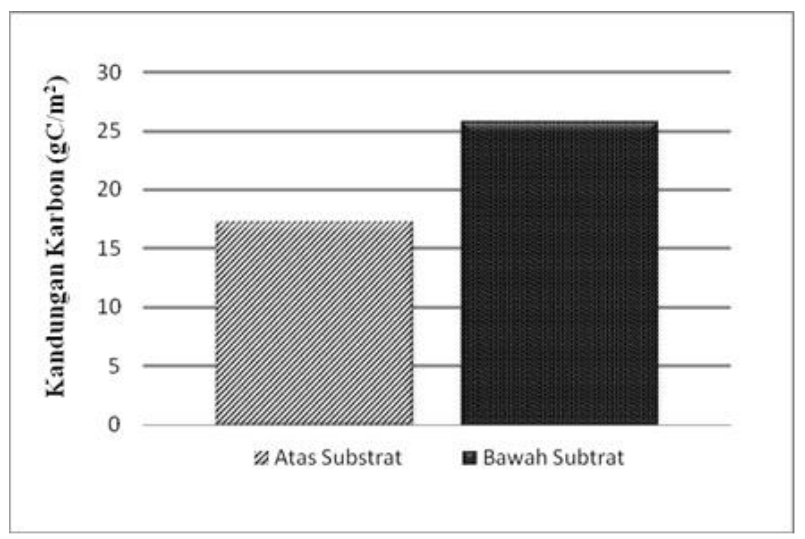

Gambar 7. Kandungan karbon lamun atas substrat dan bawah substrat

\section{Simpulan}

Kandungan karbon pada lamun bagian atas substrat (daun) sebesar $17.18 \mathrm{gC} / \mathrm{m}^{2}$. Kandungan karbon bagian atas susbtrat dipengaruhi dengan posisinya yang langsung terpapar oleh kualitas fisik perairan, seperti gelombang dan kekeringan akibat paparan cahaya matahari.

Kandungan karbon pada lamun bagian bawah substrat (akar dan rhizoma) sebesar $25.70 \mathrm{gC} / \mathrm{m}^{2}$. Kandungan karbon pada bagian bawah substrat sangat penting karena karbon akan terakumulasi di sedimen.

Jenis lamun yang didapat di Pantai Mengiat yaitu Thalassodendron ciliatum, Thalassia hemprichii, Cymodocea serrulata, Halodule uninervis, Cymodocea rotundata, dan Syringodium isoetifolium, dimana kandungan karbon tertinggi yaitu $62.46 \mathrm{gC} / \mathrm{m}^{2}$ dimiliki jenis Thalassodendron ciliatum, sedangkan kandungan karbon terendah yaitu $17.25 \mathrm{gC} / \mathrm{m}^{2}$ dimiliki jenis Syringodium isoetifolium.

\section{Ucapan terimakasih}

Penulis mengucapkan terima kasih kepada seluruh pihak yang telah memberikan masukan dan bimbingan dalam pembuatan jurnal ilmiah ini. Terimakasih yang sebesar - besarnya kepada Fakultas Kelautan dan Perikanan atas fasilitas yang telah diberikan.

\section{Daftar Pustaka}

Arthana, I. W. (2012). Jenis dan Kerapatan Padang Lamun di Pantai Sanur Bali. Jurnal Bumi Lestari, 5(2), $1-10$.

Assuyuti, Y. M., Rijaluddin, A. F., Ramadhan, F., \& Zikrillah, R. B. (2016). Estimasi jumlah biomassa lamun di Pulau Pramuka, Karya dan Kotok Besar, Kepulauan Seribu, Jakarta. DEPIK Jurnal Ilmu-Ilmu Perairan, Pesisir dan Perikanan, 5(2), 85-93.

Azizah, E., Nasution, S., \& Ghalib, M. (2017). Biomass and Density of Seagrass Enhalus Acoroides in the Village Waters Jago Jago of Tapanuli Tengah North Sumatera Province. Jurnal Online Mahasiswa (JOM) Bidang Perikanan dan Ilmu Kelautan, 4(2), 1-10.

Barus, T. A. (2004). Faktor-faktor lingkungan abiotik dan keanekaragaman plankton sebagai indikator kualitas perairan danau Toba. Jurnal Manusia dan Lingkungan, 11(2), 64-72.

Christon, C., Djunaedi, O. S., \& Purba, N. P. (2012). Pengaruh Tinggi Pasang Surut Terhadap Pertumbuhan dan Biomassa Daun Lamaun Enhalus acoroides di Pulau Pari Kepulauan Seribu Jakarta. Jurnal Perikanan dan Kelautan. 3(3), 287-294.

Djunaedi, O. S., \& Purba, N. P. (2012). Pengaruh Tinggi Pasang Surut Terhadap Pertumbuhan dan Biomassa Daun Lamun Enhalus acoroides di Pulau Pari Kepulauan Seribu Jakarta. Jurnal Perikanan Kelautan, 3(3), 287-294.

Faiqoh, E., Wiyanto, D. B., \& Astrawan, I. G. B. (2017). Peranan Padang Lamun Selatan Bali Sebagai Pendukung Kelimpahan Ikan di Perairan Bali. Journal of Marine and Aquatic Sciences, 3(1), 10-18.

Fajarwati, D. S., Setianingsih, A. I., \& Muzani. (2015). Analisis Kondisi Lamun (Seagrass) di Perairan Pulau Pramuka, Kepulauan Seribu. Jurnal SPATIAL Wahana Komunikasi dan Informasi Geografi, 13(1), 22-32.

Graha, Y. I., Arthana, I. W., \& Karang, I. W. G. A. (2016). Simpanan Karbon Padang Lamun di Kawasan Pantai Sanur, Kota Denpasar. Ecotrophic: Journal of Environmental Science, 10(1), 46-53. 
Hafiludin, H. (2011). Karakteristik Proksimat dan Kandungan Senyawa Kimia Daging Putih dan Daging Merah Ikan Tongkol (Euthynnus affinis). Indonesian Journal of Marine Science and Technology, 4(1), 1-10.

Handayani. (2015). Analisis Kualitas Kimia Susu Pasteurisasi dengan Penambahan Sari Buah Sirsak. Skripsi. Makassar, Indonesia: Fakultas Peternakan Universitas Hasanuddin Makassar.

Hartati, R., Pratikto, I., \& Pratiwi, T. N. (2017). Biomassa dan Estimasi Simpanan Karbon pada Ekosistem Padang Lamun di Pulau Menjangan Kecil dan Pulau Sintok, Kepulauan Karimunjawa. Jurnal Buletin Oseanografi Marina, 6(1), 74-81.

Helrich, K. (1990). Official Method of Analysis of the Association of Official Analytical Chemists. (15th ed.). Arlington, VA, USA: Association of Official Analytical Chemists.

Hilwan, I., \& Nurjannah, A. S. (2014). Potensi Simpanan Karbon Pada Tegakan Revegetasi Lahan Pasca Tambang di PT Jorong Barutama Greston, Kalimantan Selatan. Jurnal Silvikultur Tropika, 5(3), 188-195.

Huriawati, F., Yuhanna, W. L., \& Mayasari, T. (2016). Pengaruh Metode Pengeringan Terhadap Kualitas Serbuk Seresah Enhalus acoroides dari Pantai Tawang Pacitan. Bioeksperimen: Jurnal Penelitian Biologi, 2(1), 35-43.

Ira, I., Oetama, D., \& Juliati, J. (2013). Kerapatan dan Penutupan Lamun Pada Daerah Tanggul Pemecah Ombak di Perairan Desa Terebino Propinsi Sulawesi Tengah. Aquasains: Jurnal Ilmu Perikanan dan Sumberdaya Perairan, 2(1), 89-96.

Kurnia, M., Pharmawati, M., \& Yusup, D. S. (2015). Jenis-Jenis Lamun di Pantai Lembongan, Nusa Lembongan dan Analisisnya dengan Pcr Ruas rbcL. SIMBIOSIS Journal of Biological Sciences, 3(2), 330-333.

Nasdwiana. (2016). Analisis Hubungan Antara Konsentrasi Karbon Organik di Sedimen dengan Laju Pertumbuhan dan Biomassa Lamun Enhalus acoroides dan Thalassia hemprichii. Skripsi. Makassar, Indonesia: Fakultas Ilmu Kelautan dan Perikanan, Universitas Hasanuddin.

Nurzahraeni. (2014). Keragaman Jenis dan Kondisi Padang Lamun Di Perairan Pulau Panjang Kepulauan Derawan Kalimantan Timur. Skripsi. Makassar, Indonesia: Jurusan Ilmu Kelautan Fakultas Ilmu Kelautan dan Perikanan Universitas Hasanuddin Makassar.

MNLH. (2004). KKeputusan Menteri Negara Lingkungan Hidup Nomor 4 Tahun 2001 tentang Kriteria Baku Kerusakan Terumbu Karang. JakartaIndonesia: Menteri Negara Lingkungan Hidup.

Pratiwi, A. R., Willian, N., \& Pratomo, A. (2016). Analisis Kandungan Logam Berat $(\mathrm{Pb})$ dan $(\mathrm{Cd})$ Terhadap Lamun (Enhalus acoroides) Sebagai Bioindikator di
Perairan Tanjung Lanjut Kota Tanjungpinang. Jurnal Zarah, 2(1), 1-10.

Putra, I. A., Thamrin, T., \& Zulkifli, Z. (2017). Potensi Penyimpanan Karbon Pada Lamun (Cymodocea serrulata) di Perairan Pulau Poncan Sibolga Provinsi Sumatera Utara. Jurnal Online Mahasiswa (JOM) Bidang Perikanan dan Ilmu Kelautan, 4(2), 1-12.

Rahmawati, S. (2011). Estimasi Cadangan Karbon Pada Komunitas Lamun Di Pulau Pari, Taman Nasional Kepulauan Seribu, Jakarta. Jurnal Segara, 7(1), 1-12.

Rahman, A. A., Nur, A. I., \& Ramli, M. (2016). Studi Laju Pertumbuhan Lamun (Enhalus acoroides) di Perairan Pantai Desa Tanjung Tiram Kabupaten Konawe Selatan. Jurnal Sapa Laut (Jurnal Ilmu Kelautan), 1(1), 10-16.

Riniatsih, I. (2016). Distribusi Muatan Padatan Tersuspensi (MPT) di Padang Lamun di Perairan Teluk Awur dan Pantai Prawean Jepara. Jurnal Kelautan Tropis, 18(3), 121-126.

Rustam, A., Kepel, T. L., Afiati, R. N., Salim, H. L., Astrid, M., Daulat, A., Mangindan, P., Sudirman, N., Puspitaningsih, Y., Dwiyanti, D., \& Hutahaean, A. (2014). Peran Ekosistem Lamun Sebagai Blue Carbon Dalam Mitigasi Perubahan Iklim, Studi Kasus Tanjung Lesung, Banten. Jurnal Segara, 10(2), 107-117.

Santoso, B., Dharma, I. G. B. S., \& Faiqoh, E. (2018). Pertumbuhan dan Produktivitas Daun Lamun Thalassia hemprichii (Ehrenb) Ascherson di Perairan Tanjung Benoa, Bali. Journal of Marine and Aquatic Sciences, 4(2), 278-285.

Setiawan F. (2012). Deteksi Perubahan Padang Lamun Menggunakan Teknologi Penginderaan Jauh dan Kaitannya dengan Kemampuan Menyimpan Karbon di Perairan Teluk Banten. Jurnal Perikana dan Kelautan, 3(3), 275-286.

Supriadi, S., Kaswadji, R. F., Bengen, D. G., \& Hutomo, M. (2012). Produktivitas Komunitas Lamun di Pulau Barranglompo Makassar. Jurnal Akuatika, 3(2), 159-168.

Supriadi, S., Kaswadji, R. F., Bengen, D. G., \& Hutomo, M. (2014). Carbon Stock of Seagrass Community in Barranglompo Island, Makassar. Indonesian Journal of Marine Sciences, 19(1), 1-10.

Sudiarta, I. K., \& Sudiarta, I. G. (2011). Status Kondisi dan Identifikasi Permasalahan Kerusakan Padang Lamun di Bali. Jurnal Mitra Bahari, 5(2), 103-126.

Uthbah, Z., Sudiana, E., \& Yani E. (2017).Analisis Biomasa dan Cadangan Karbon Pada Berbagai Umur Tegakan Damar (Agathis Dammara (Lamb.) Rich.) di KPH Banyumas Timur. Journal Scripta Biologica, 4(2), 119-124.

Widyasari, N. A. E., \& Saharjo, B. H. (2010). Pendugaan biomassa dan potensi karbon terikat di atas permukaan tanah pada hutan rawa gambut bekas terbakar di Sumatera Selatan. Jurnal Ilmu Pertanian Indonesia, 15(1), 41-49. 
Yuniwati, Y., \& Suhartana, S. (2014). Potensi Karbon Pada Limbah Pemanenan Kayu Acacia crassicarpa (Carbon Potential of Waste Timber Harvesting Acacia Crassicarpa). Jurnal Ilmu Lingkungan, 12(1), 21-31.
Yusup, D. S., \& Asy'ari, A. (2010). Komunitas Tumbuhan Lamun di Kawasan Perairan Sekitar Denpasar. Dalam Prosiding Seminar Nasional Biologi: Biodiversitas dan Bioteknologi Sumberdaya Akuatik. Purwokerto, Indonesia, 26 Juni 2010 (pp. 26-29).

(C) 2018 by the authors; licensee Udayana University, Indonesia. This article is an open access article distributed under the terms and conditions of the Creative Commons Attribution license (http://creativecommons.org/licenses/by/3.0/). 